\title{
Assessment of Radiation Risk from Background Radiation Exposures in Selected Hospitals within Makurdi Metropolis, North-Central, Nigeria
}

\author{
O. Y. Omogunloye, A. T. Adepoju, and P. Kururimam
}

\section{ABSTRACT}

In this study, a radiation alert meter was used to measure background ionizing radiation levels in four hospitals in Makurdi Metropolis, Benue State, North Central, Nigeria. This aimed to determine the radiological health implications of the measured background ionizing radiation study area's populace. The background ionizing radiation exposure rate (indoor and outdoor) measured ranged from 0.0014 to $0.0019 \mathrm{mRhr}^{-1}$ with average value $0.0017 \mathrm{mRhr}^{-1}, 0.0015$ to $0.0024 \mathrm{mRhr}^{-1}$ with average value $0.0019 \mathrm{mRhr}^{-1}, 0.0013$ to $0.0025 \mathrm{mRhr}^{-1}$ with average value $0.0018 \mathrm{mRhr}^{-1}$ and 0.0012 to $0.0024 \mathrm{mRhr}^{-1}$ with average value $0.0018 \mathrm{mRhr}^{-1}$ for the selected hospitals $A, B, C$ and $D$, respectively. The study showed that the mean equivalent dose rate levels are within the international commission on radiological protection's standard permissible limits. The mean annual effective dose equivalent (indoor and outdoor) for all the selected hospitals is within the recommended permissible limits of $1.00 \mathrm{mSvy}^{-1}$ for the general public. In the selected hospitals $\mathrm{A}, \mathrm{B}, \mathrm{C}$, and $\mathrm{D}$, the estimated Dorgan values for the lungs, ovaries, bone marrow, testes, kidney, liver, and wholebody due to radiation exposure and inhalation are below tolerable international limits of $\mathbf{1 . 0} \mathbf{~ m S v}$ yearly. Hence the selected hospitals are radiologically safe.

Keywords: Annual Effective Dose Equivalent; Background ionizing radiation; Effective Dose; Exposure Rate; Radiation Alert Meter; Radiological Health Hazard Indices.

Published Online: August 17, 2021

ISSN: $2684-4451$

DOI :10.24018/ejphysics.2021.3.4.91

\section{O. Y. Omogunloye*}

Department of Physical Sciences, Olusegun Agagu University of Science and Technology, Okitipupa, Ondo State, Nigeria.

(e-mail: oy.omogunloye ${ }^{@}$ osustech.edu.ng) A. T. Adepoju

Department of Physics, Federal University of Agriculture, Makurdi, Benue State, Nigeria.

(e-mail: bayolastic @ gmail.com)

P. Kururimam

Department of Physics, Federal University of Agriculture, Makurdi, Benue State, Nigeria.

(e-mail:paulkururimam ${ }^{\circledR}$ gmail.com).

*Corresponding Author

\section{INTRODUCTION}

It is a well-known fact that most of the world's population lives in an environment where we are exposed to varying radiation levels daily. The radiation may be from natural sources, such as the soils' radionuclides, cosmic radiation due to ionization of gases in the atmosphere, radon gas, granite rock, water, sediments [11], or artificial sources from x-ray machines, building materials, radioactive waste from nuclear reactors, the fallout from nuclear weapons testing and nuclear accidents. The amount of radiation emitted in the environment varies depending on geographical locations. Ionizing and non-ionizing radiations are the two types of radiation. Ionizing radiation is a type of radiation that can produce ions, disrupting life processes by causing ionization in a matter when irradiated, which is more detrimental to the human body than non-ionizing radiation [11]. Non-ionizing radiations, on the other hand, do not create ions in irradiated matter, even though they may harm human health in different ways [11]. Ionizing radiation has recently received a lot of attention because of its capacity to break atoms and create positive ions and negative electrons, which inflict biological damage to humans when exposed to it. X-rays, gamma rays, alpha particles, beta particles, neutrons, and cosmic rays are examples of ionizing radiation.
Although ionizing radiation is harmful, people have immensely benefited from its uses in the medical industry ever since its discovery. Ionizing radiation is helpful in the medical sector for performing diagnostic imaging and therapeutic procedures, which provide vital information about patients' health to medical doctors to help them ensure that proper medical treatment and attention are given to patients when the need arises [6]. However, these procedures also have a high probability of exposing many people to radiological risks, especially when the exposure rates are higher than the recommended permissible level by radiation safety regulatory bodies. Background indoor and outdoor radiation has over the years become a public health concern. It is, therefore, imperative to ascertain its level within strategic areas in our hospitals/radiological center for monitoring and compliance with international standards.

Although several studies have been conducted in Nigeria to determine the levels of natural background radiation in hospitals, [8] investigated the radiation risk assessment of background radiation exposures in South-South Nigeria hospitals. They reported an average indoor and outdoor exposure dose rates of $0.013 \pm 0.003$ and $0.015 \pm 0.003 \mathrm{mRh}^{-1}$ at the University of Uyo Teaching Hospital, $0.015 \pm 0.005$ and $0.015 \pm 0.005 \mathrm{mRh}^{-1}$ at the University of Port Harcourt Teaching Hospital, and $0.014 \pm 0.003$ and $0.013 \pm 0.003 \mathrm{mRh}^{-1}$ 
at the Braithwaite Memorial Specialist Hospital, respectively.

Thus, this study aims to measure the background ionizing radiation of selected hospitals within Makurdi Metropolis, Benue State, North Central, Nigeria, to determine the radiological implications of the measured background ionizing radiation on the populace of the study area.

\section{SElection OF Sites}

For the present study, four hospitals with functioning radiological departments within the Makurdi metropolis were randomly selected. The selected hospitals are University staff clinic of the University of Agriculture denoted as A, Madonna hospital denoted as B, University of Agriculture Veterinary teaching hospital denoted as C, and Bishop Murray hospital denoted as D all within Makurdi Metropolis, Benue state, Nigeria.

\section{MEASUREMENT AND METHODS}

The instrument used in this radiation survey is Inspector Alert Meter with serial number SN: 35541. The Inspector Alert Meter detects radiation using a Geiger-Muller tube. Each time radiation goes through the tube and induces ionization, the Geiger tube generates an electric current pulse. Each pulse is detected electrically and recorded as a count. The count is shown in different units such as count per minute (CPM), milli-Roentgens per hour $\left(\mathrm{mRhr}^{-1}\right)$, Counts per second (CPS), and microSieverts per hour $\left(\mathrm{Svhr}^{-1}\right)$. Due to the unpredictable nature of radioactivity, the number of counts identified by the Inspector Alert Meter varies from reading to reading. To measure the indoor and outdoor dose rate, the Inspector Alert Meter was held at a distance of $1.0 \mathrm{~m}$ above the ground to record the reading when the meter was switched on. At each measurement point, four sets of readings were taken, and the mean values were calculated. The background ionizing radiation exposure rate readings were taken in milli-Roentgen per hour $\left(\mathrm{mRhr}^{-1}\right)$ directly from the display screen of the Inspector Alert Meter. The background ionizing radiation exposure rate obtained was used to assess the radiological health implications in the immediate environment. The radiation effective doses to different body organs by calculating some radiological health hazard indices using well-established mathematical relations. The indoor background ionizing radiation levels were measured in the $\mathrm{X}$-ray and waiting rooms, while that of the outdoor was measured in the selected hospitals' fronts.

\section{RESULTS AND DISCUSSION}

Tables I and II show the measured background ionizing radiation exposure rate and the related radiological health hazard indices in the selected hospitals. The results for the effective dose to different body organs are shown in Tables III and IV.

The absorbed dose rate in air, Annual effective dose equivalent (AEDE), Excess lifetime cancer risk (ELCR), and effective dose to organs ( $D_{\text {organ }}$ ) are the different radiological health hazard indices used in evaluating the radiation safety status of the examined environment.

\section{A. Background Ionizing Radiation Exposure Rate Level}

The background ionizing radiation exposure rate (indoor and outdoor) measured for the selected hospitals A, B, C and $\mathrm{D}$ ranged from 0.0014 to $0.0019 \mathrm{mRhr}^{-1}$ with average value $0.0017 \mathrm{mRhr}^{-1}, 0.0015$ to $0.0024 \mathrm{mRhr}^{-1}$ with average value $0.0019 \mathrm{mRhr}^{-1}, 0.0013$ to $0.0025 \mathrm{mRhr}^{-1}$ with average value $0.0018 \mathrm{mRhr}^{-1}$ and 0.0012 to $0.0024 \mathrm{mRhr}^{-1}$ with average value $0.0018 \mathrm{mRhr}^{-1}$, respectively.

The highest exposure rate was recorded at the X-ray room of all the selected hospitals; this could be due to the presence of radiation sources ( $\mathrm{x}$-ray machines and other equipment). This suggests that during $\mathrm{x}$-ray examinations, patients and staff are usually exposed to higher radiation levels, which could be owing to a lack of suitable shielding materials. The measured background ionizing radiation exposure rate levels in all the selected hospitals are lower than the recommended permissible limit of $0.013 \mathrm{mRhr}^{-1}$ [5]. The low background ionizing radiation exposure rate reported for the studied hospitals implies non-radiological contamination, thereby are radiologically safe and healthy for the general public of the study area.

\section{B. Absorbed Dose Rate (D)}

The absorbed dose rate measures the amount of radiation deposited per unit time, so it is crucial in radiation risk analysis. To avoid any somatic, epidemiological, or radiological health effects, the International Commission on Radiological Protection [4] proposed and set the maximum permissible level for non-radionuclide industrial workers and the general public at $1.0 \mathrm{mSvy}^{-1}$.

According to [10], the measured background ionizing radiation exposure levels were converted to radiation absorbed dose rate in the air using (1).

$$
1 \mathrm{mRh}^{-1}=8.7 \mathrm{nGyh}^{-1} \times 10^{3}=8700 \mathrm{nGyh}^{-1}
$$

For the selected hospitals A, B, C, and D, the estimated radiation absorbed dose rate (indoor) ranged from 14.79 to $16.53 \mathrm{nGyh}^{-1}$ with a mean value of $15.66 \mathrm{nGyh}^{-1}, 13.05$ to $20.88 \mathrm{nGyh}^{-1}$ with a mean value of $16.97 \mathrm{nGyh}^{-1}, 11.31$ to $21.75 \mathrm{nGyh}^{-1}$ with a mean value of $16.53 \mathrm{nGyh}^{-1}$ and 15.66 to $20.88 \mathrm{nGyh}^{-1}$ with a mean value of $18.27 \mathrm{nGyh}^{-1}$ while the estimated radiation absorbed dose rates (outdoor) are $0.0014 \mathrm{nGyh}^{-1}, 0.0017 \mathrm{nGyh}^{-1}, 0.0016 \mathrm{nGyh}^{-1}$ and $0.0012 \mathrm{nGyh}^{-1}$, respectively. These dose rates arising from background ionizing radiation exposure in the studied locations are far lower than the recorded world weighted average of $59.00 \mathrm{nGyh}^{-1}$ [1]; [7] and recommended safe limit of $84.0 \mathrm{nGyh}^{-1}$ [12].

\section{C. Annual Effective Dose Equivalent (AEDE)}

The annual effective dose equivalent received by a member is derived using a dose conversion factor of 0.7 SvGy-1 and occupancy factors of $0.2(5 / 24)$ and $0.8(19 / 24)$ for outdoor and indoor, respectively [13]. The following equations are used to obtain AEDE:

- Annual Effective Dose Equivalent(outdoor) (AEDE) 
$\operatorname{AEDE}\left(\mathrm{mSv} \mathrm{y}^{-1}\right)=\mathrm{D}\left(\mathrm{nGy} \mathrm{h}^{-1}\right) \times 8760 \mathrm{~h} \mathrm{y}^{-1} \times 0.2 \times 0.7 \mathrm{~Sv}$ $\mathrm{Gy}^{-1}$

- Annual Effective Dose Equivalent(indoor) (AEDE)

$\operatorname{AEDE}\left(\mathrm{mSv} \mathrm{y}^{-1}\right)=\mathrm{D}\left(\mathrm{nGy} \mathrm{h}^{-1}\right) \times 8760 \mathrm{~h} \mathrm{y}^{-1} \times 0.8 \times 0.7 \mathrm{~Sv}$ $\mathrm{Gy}^{-1}$

The AEDE indoor takes place within a building and evaluates the radiation dangers posed by building materials, while AEDE outdoor involves considering the absorbed dose emitted from radionuclides in the environment.

For the selected hospitals A, B, C, and D, the calculated annual effective dose equivalent (indoor) ranges from 0.073 to $0.081 \mathrm{mSvy}^{-1}$ with an average value of $0.077 \mathrm{mSvy}^{-1}$, 0.064 to $0.102 \mathrm{mSvy}^{-1}$ with an average value of $0.083 \mathrm{mSvy}^{-1}, 0.055$ to $0.107 \mathrm{mSvy}^{-1}$ with an average value of $0.081 \mathrm{mSvy}^{-1}$ and 0.077 to $0.102 \mathrm{mSvy}^{-1}$ with an average value of $0.090 \mathrm{mSvy}^{-1}$, respectively while the calculated annual effective dose equivalent (outdoor) are 0.015, 0.018, 0.017 and $0.013 \mathrm{mSvy}^{-1}$, respectively. The calculated indoor and outdoor annual effective dose equivalent in all the selected hospitals is lower than the ICRP and UNSCEAR recommended permissible limits of $1.00 \mathrm{mSvy}^{-1}$ for the general public.

\section{Effective Dose to Different Body Organs ( $\left.D_{\text {organ }}\right)$}

The effective dose to organs ( $D_{\text {organ }}$ ) measures the amount of radiation dose intake to various organs and tissues of the body. The $\mathrm{D}_{\text {organ }}$ of the body due to inhalation is calculated using equation 4 as given by [2].

$\mathrm{D}_{\text {organ }}\left(\mathrm{mSvy}^{-1}\right)=\operatorname{AEDE}_{\mathrm{M}} \mathrm{X} \mathrm{F}$

where $\mathrm{AEDE}_{\mathrm{M}}$ is the mean annual effective dose equivalent (indoor and outdoor) and $\mathrm{F}$ is the conversion factor of organ dose from air dose. According to ICRP [3], the F values for the lungs, ovaries, bone marrow, testes, kidney, liver, and entire body are $0.64,0.58,0.69,0.82,0.62,0.46$, and 0.68 , respectively.

Tables III and IV show the estimated $\mathrm{D}_{\text {organ }}$ values for the lungs, ovaries, bone marrow, testes, kidney, liver, and entire body due to radiation exposure and inhalation in the selected hospitals. Fig. 1 and 2 show the variation of $\mathrm{D}_{\text {organ }}$ to the different organs. These results are all below the tolerable international limits of $1.0 \mathrm{mSv}$ annually, which further indicates that the radiation levels of the studied area do not

constitute an immediate health effect on residents of the area. The results show that the testes have the highest sensitivity to radiation while the lungs have the lowest sensitivity to radiation, respectively.

TABLE I: BACKGROUND IONIZING RADIATION (INDOOR) EXPOSURE LEVELS AND RELATED RADIOLOGICAL HEALTH INDICES IN THE SELECTED

\begin{tabular}{|c|c|c|c|c|c|}
\hline \multicolumn{6}{|c|}{ HOSPITALS } \\
\hline $\begin{array}{l}\text { Hospital } \\
\text { code }\end{array}$ & Location & $\begin{array}{c}\text { Mean } \\
\text { exposure } \\
\text { reading } \\
\left(\mathrm{mRh}^{-1}\right) \\
\end{array}$ & $\begin{array}{c}\text { Absorbed } \\
\text { dose } \\
\left(\mathrm{nGyh}^{-1}\right)\end{array}$ & $\begin{array}{c}\text { AEDE } \\
\left(\mathrm{mSvy}^{-1}\right)\end{array}$ & $\begin{array}{r}\text { ELCR } \\
\times 10^{-3}\end{array}$ \\
\hline $\mathrm{A}$ & X-ray room & 0.0019 & 16.53 & 0.081 & 0.284 \\
\hline A & $\begin{array}{l}\text { Waiting } \\
\text { room }\end{array}$ & 0.0017 & 14.79 & 0.073 & 0.254 \\
\hline B & X-ray room & 0.0024 & 20.88 & 0.102 & 0.359 \\
\hline B & $\begin{array}{l}\text { Waiting } \\
\text { room }\end{array}$ & 0.0015 & 13.05 & 0.064 & 0.224 \\
\hline $\mathrm{C}$ & X-ray room & 0.0025 & 21.75 & 0.107 & 0.373 \\
\hline $\mathrm{C}$ & $\begin{array}{l}\text { Waiting } \\
\text { room }\end{array}$ & 0.0013 & 11.31 & 0.055 & 0.194 \\
\hline $\mathrm{D}$ & $\mathrm{x}$-ray room & 0.0024 & 20.88 & 0.102 & 0.359 \\
\hline $\mathrm{D}$ & $\begin{array}{l}\text { Waiting } \\
\text { room }\end{array}$ & 0.0018 & 15.66 & 0.077 & 0.269 \\
\hline Mean & & 0.0019 & 16.86 & 0.083 & 0.289 \\
\hline
\end{tabular}

TABLE II: BACKGROUND IONIZING RADIATION (OUTDOOR) EXPOSURE LEVELS AND RELATED RADIOLOGICAL HEALTH INDICES IN THE SELECTED HOSPITALS

\begin{tabular}{cccccc}
\hline $\begin{array}{c}\text { Hospital } \\
\text { code }\end{array}$ & Location & $\begin{array}{c}\text { Mean } \\
\text { exposure } \\
\text { reading } \\
\left(\mathrm{mRh}^{-1}\right)\end{array}$ & $\begin{array}{c}\text { Absorbed } \\
\text { dose } \\
\left(\mathrm{nGyh}^{-1}\right)\end{array}$ & $\begin{array}{c}\text { AEDE } \\
\left(\mathrm{mSvy}^{-1}\right)\end{array}$ & $\begin{array}{c}\text { ELCR } \\
\times 10^{-3}\end{array}$ \\
\hline A & Front & 0.0014 & 12.18 & 0.015 & 0.053 \\
B & Front & 0.0017 & 14.79 & 0.018 & 0.063 \\
C & Front & 0.0016 & 13.92 & 0.017 & 0.060 \\
D & Front & 0.0012 & 10.44 & 0.013 & 0.046 \\
Mean & & 0.0015 & 12.83 & 0.016 & 0.055 \\
\hline
\end{tabular}

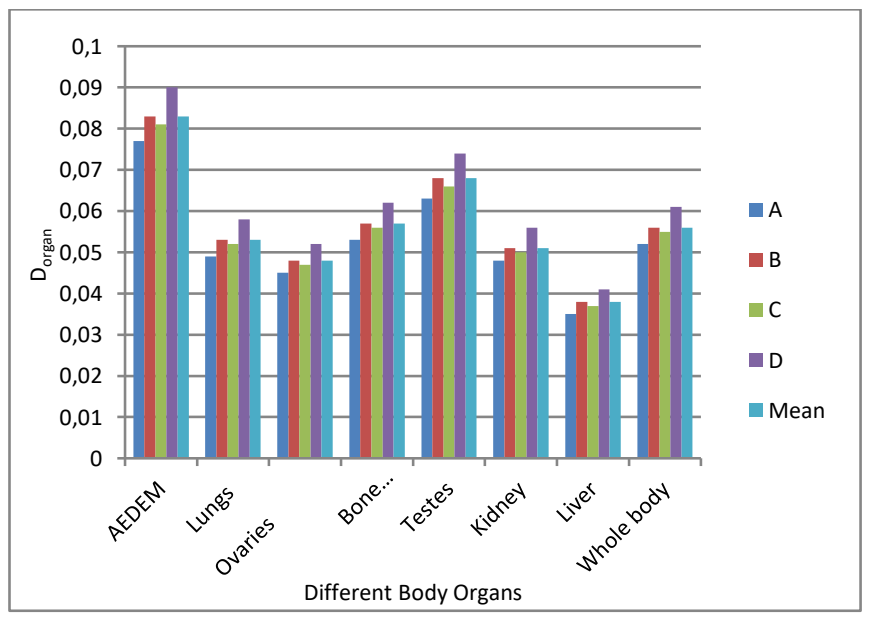

Fig.1. Mean annual effective dose equivalent (indoor) and effective dose to organs $\left(\mathrm{D}_{\text {organ }}\right)$.

TABLE III: MEAN ANNUAL EFFECTIVE DOSE EQUIVALENT (INDOOR) AND EFFECTIVE DOSE TO ORGANS (D ORGAN )

\begin{tabular}{ccccccccc}
\hline $\begin{array}{c}\text { Hospital } \\
\text { code }\end{array}$ & AEDE $_{\mathrm{M}}$ & Lungs & Ovaries & $\begin{array}{c}\text { Bone } \\
\text { arrow }\end{array}$ & Testes & Kidney & Liver & $\begin{array}{c}\text { Whole- } \\
\text { body }\end{array}$ \\
\hline A & 0.077 & 0.049 & 0.045 & 0.053 & 0.063 & 0.048 & 0.035 & 0.052 \\
B & 0.083 & 0.053 & 0.048 & 0.057 & 0.068 & 0.051 & 0.038 & 0.056 \\
C & 0.081 & 0.052 & 0.047 & 0.056 & 0.066 & 0.050 & 0.037 & 0.055 \\
D & 0.090 & 0.058 & 0.052 & 0.062 & 0.074 & 0.056 & 0.041 & 0.061 \\
Mean & 0.083 & 0.053 & 0.048 & 0.057 & 0.068 & 0.051 & 0.038 & 0.056 \\
\hline
\end{tabular}

TABLE IV: MEAN ANNUAL EFFECTIVE DOSE EQUIVALENT (OUTDOOR) AND EFFECTIVE DOSE TO ORGANS (D ORGAN )

\begin{tabular}{ccccccccc}
\hline $\begin{array}{c}\text { Hospital } \\
\text { code }\end{array}$ & AEDE $_{\mathrm{M}}$ & Lungs & Ovaries & $\begin{array}{c}\text { Bone } \\
\text { marrow }\end{array}$ & Testes & Kidney & Liver & $\begin{array}{c}\text { Whole- } \\
\text { body }\end{array}$ \\
\hline A & 0.015 & 0.010 & 0.009 & 0.010 & 0.012 & 0.009 & 0.007 & 0.010 \\
B & 0.018 & 0.012 & 0.010 & 0.012 & 0.015 & 0.011 & 0.008 & 0.012 \\
C & 0.017 & 0.011 & 0.010 & 0.012 & 0.014 & 0.011 & 0.008 & 0.012 \\
D & 0.013 & 0.008 & 0.008 & 0.009 & 0.011 & 0.008 & 0.006 & 0.009 \\
Mean & 0.016 & 0.010 & 0.009 & 0.011 & 0.013 & 0.010 & 0.007 & 0.011 \\
\hline
\end{tabular}




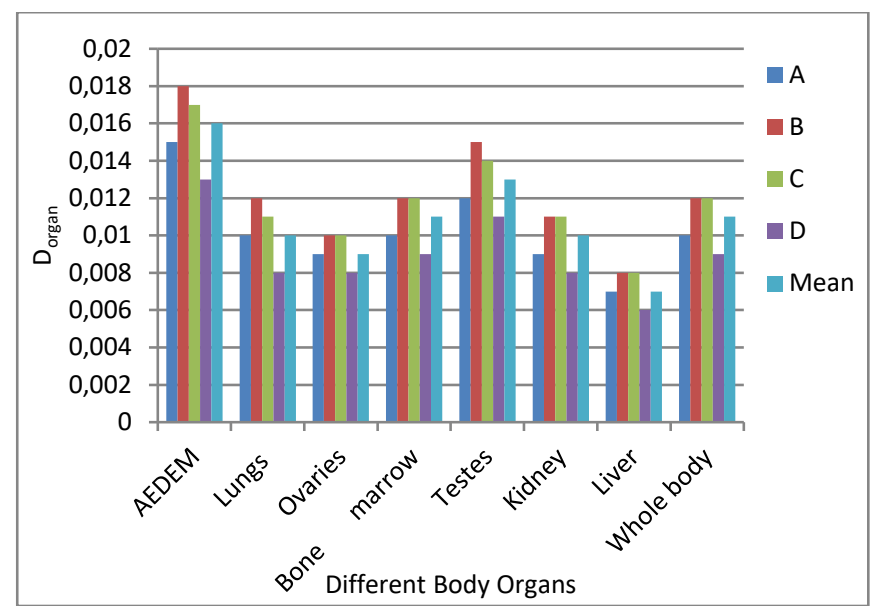

Fig. 2. Mean annual effective dose equivalent (outdoor) and effective dose to organs $\left(\mathrm{D}_{\text {organ }}\right)$.

\section{E. Excess Lifetime Cancer Risk (ELCR)}

This is concerned with the likelihood of developing cancer throughout a lifetime for a particular degree of exposure. It is expressed as a number representing the number of cancers expected in a specific number of people after exposure to a carcinogen at a particular dose. It's worth mentioning that an increase in the ELCR leads to a corresponding increase in the risk of developing breast, prostate, or even blood cancer. Excess lifetime cancer risk (ELCR) is determined using equation 5 [9].

$\mathrm{ELCR}=\mathrm{AEDE} \times \mathrm{DL} \times \mathrm{RF}$

where AEDE is the Annual Equivalent Dose Equivalent, DL is the average duration of life (estimated to 70 years) and RF is the Risk Factor $\left(\mathrm{Sv}^{-1}\right)$, i.e., fatal cancer risk per Sievert. For stochastic effects, ICRP uses RF as 0.05 for the public [9].

The calculated values for the indoor ELCR of the selected hospitals $\mathrm{A}, \mathrm{B}, \mathrm{C}$ and $\mathrm{D}$ ranges from $0.257 \times 10^{-3}$ to $0.284 \times 10^{-3}$ with a mean value $0.270 \times 10^{-3}, 0.244 \times 10^{-3}$ to $0.357 \times 10^{-3}$ with a mean value $0.291 \times 10^{-3}, 0.193 \times 10^{-3}$ to $0.375 \times 10^{-3}$ with a mean value $0.284 \times 10^{-3}$ and $0.270 \times 10^{-3}$ to $0.357 \times 10^{-3}$ with a mean value $0.313 \times 10^{-3}$, respectively while the calculated values for the outdoor ELCR of the selected hospitals A, B, C and D are $0.053 \times 10^{-3}, 0.063 \times 10^{-3}$, $0.060 \times 10^{-3}$ and $0.046 \times 10^{-3}$, respectively. The mean indoor ELCR values obtained for hospitals B and D are slightly higher than the worldwide average value of $0.29 \times 10^{-3}$ while that of hospitals A, C and outdoor ELCR values of all the selected hospitals are lower compared to the worldwide average value of $0.29 \times 10^{-3}$. This somewhat higher result for the indoor excess lifetime cancer risk for hospitals B and D suggests that residents who intend to spend their entire lives in the area are at risk of developing cancer.

\section{CONCLUSION}

A radiation alarm meter was used to take indoor and outdoor measurements of background ionizing radiation levels at four hospitals within Makurdi Metropolis. The measurements were taken at three different locations across the hospitals. The analysis found that the mean equivalent dose rate levels are within the international commission on radiological protection's standard acceptable limits (ICRP). The study showed that the mean equivalent dose rate levels in all the selected hospitals are within the standard permissible limits set by the international commission on radiological protection. The mean indoor and outdoor annual effective dose equivalent for all the selected hospitals is within ICRP and UNSCEAR recommended permissible limits of $1.00 \mathrm{mSvy}^{-1}$ for the general public [5], [12]. In the selected hospitals, the estimated $D_{\text {organ }}$ values for the lungs, ovaries, bone marrow, testes, kidney, liver, and whole-body due to radiation exposure and inhalation are all within the worldwide acceptable limits of $1.0 \mathrm{mSv}$ annually. Hence the selected hospitals are radiologically safe.

\section{RECOMMENDATIONS}

Based on the findings of this study, we, as a result of this, recommend that measures be put in place at these hospitals through regular workplace monitoring and quality control of radiation facilities to ensure that the acceptable limit is not exceeded. These hospitals' radiation safety officers should ensure that staff uses protective devices and dosimeters for proper personnel monitoring.

\section{REFERENCES}

[1] Agbalagba O.E., "Assessment of excess lifetime cancer risk from gamma radiation levels in Effurun and Warri city of Delta state, Nigeria," Journal of Taibah University for Science, 2017, 11(3):367380 .

[2] Darwish D.A.E, Abul-Nasr KTM, El-Khayatt AM., "The assessment of natural radioactivity and its associated radiological hazards and dose parameters in granite samples from South Sinai, Egypt," Journal of Radiation Research and Applied Sciences, 2015, 8:17-25.

[3] International Commission on Radiological Protection (ICRP), International Commission on Radiological Protection Age-dependent Doses to Members of the Public from Intake of Radionuclides. Part 5, Compilation of Ingestion and Inhalation Coefficients ICRP Publication 72, Pergamon Press, Oxford, 1996.

[4] International Commission on Radiological Protection (ICRP), The 1995-1999 Recommendation of the International Commission of Radiological Protection. Publication 60. Pergamon Press, 1999.

[5] International Commission on Radiological Protection (ICRP) (2007). The 2007 Recommendations of the International Commission on Radiological Protection: Annals of the ICRP Publication Elsevier. 103:2-4.

[6] Lemela H., Arvela, H. and Hyvönen H., "Indoor and outdoor gamma radiation in Finland," Radiat. Prot. Dosim., 1995, 59(1): 25-32.

[7] Monica S, Visnu Prasad A.K, Soniya S.R and Jojo P.J., "Estimation of indoor and outdoor effective doses and lifetime cancer risk from gamma dose rates along the coastal regions of Kollam district, Kerala," Radiation Protection and Environment, 2016, 39(1):38-43.

[8] Ononugbo C.P and Nwokeoji I.E., "Radiation Risk Assessment from Background Radiation Exposures in Selected Hospitals in South South, Nigeria," Current Journal of Applied Science and Technology, 2017, 22(2): 1-13.

[9] Taskin, H., M. Karavus, P. Ay, A. Topuzoglu, S. Hindiroglu and G. Karahan, "Radionuclide concentrations in soil and lifetime cancer risk due to the gamma radioactivity in Kirklareli, Turkey," Journal of Environmental Radioactivity, 2009, 100: 49-53.

[10] Ugbede F. O. and Benson I. D., "Assessment of outdoor radiation levels and radiological health hazards in Emene Industrial Layout of Enugu State, Nigeria," International Journal of Physical Sciences, 2018, Vol. 13(20), pp. 265-272.

[11] United Nations Scientific Committee on the Effects of Atomic Radiation (UNSCEAR), Sources and Effects of Ionizing Radiation", UNSCEAR 2000 Report Vol.1 to the General Assembly, with scientific annexes, United Nations Sales Publication, United Nations, New York., 2000. 
[12] United Nations Scientific Committee on the Effects of Atomic Radiation (UNSCEAR), "Sources and Effects of Ionizing Radiation", UNSCEAR 2006 Report Vol.1 to the General Assembly, with scientific annexes, United Nations Sales Publication, United Nations, New York, 2008.

[13] Veiga, R.G., N. Sanches, R. M.Anjos, K. Macario, J.Bastos, M.Iguatemy, J.G Aguiar, A.M.A. Santos, B. Mosquera, C. Carvalho, M. Baptista Filho and N.K. Umisedo, "Measurement of natural radioactivity in Brazillian beach sands," Radiation measurements, 2006, 41:189-196.

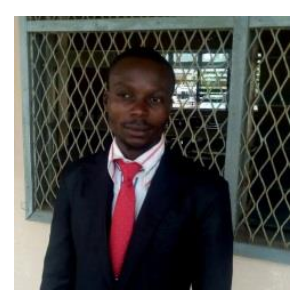

O. Y. Omogunloye was born in Ode Irele, Ondo State, Nigeria on the $10^{\text {th }}$ of November 1986. He attended the Federal University of Technology, Akure Ondo State, Nigeria where he obtained his Bachelor of Technology and Master of Technology degrees in Physics Electronics and Radiation and Health Physics in the years 2010 and 2016 respectively.

$\mathrm{He}$ is an ASSISTANT LECTURER in the Department of Physical Sciences, Olusegun Agagu University of Science and Technology, Okitipupa, Ondo State, Nigeria where he teaches Physics at undergraduate level since 2018. He has supervised some undergraduate project work in Electronics, Radiation and Health Physics.

Mr Omogunloye is planning to be a member of the Nigeria Institute of Physics.

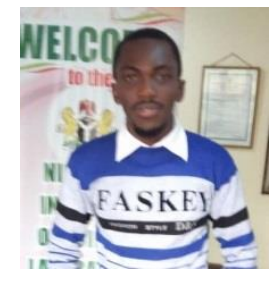

A. T. Adepoju was born in Makurdi, Benue State, Nigeria on the $13^{\text {th }}$ of January 1989 . He attended the Federal University of Agriculture Makurdi, Benue State Nigeria where he obtained his Bachelor of Science Degree in Industrial Physics in the year 2010 and later proceeded to the Federal University of Technology, Akure Ondo State, Nigeria where he obtained his Master of Technology degree in Electronics and Instrumentation Physics in the year 2016.

$\mathrm{He}$ is an ASSISTANT LECTURER with the Federal University of Agriculture, Makurdi, Benue State Nigeria where he teaches Physics at undergraduate and post-graduate Level since 2019. He had been with a Nigerian owned and funded research Institute; Nigerian Institute of Science Laboratory Technology (NISLT) prior to his engagement with the Federal University of Agriculture. He has supervised a couple of post-graduate thesis and over thirty undergraduate project works in both electronics, medical physics and material modeling with some paper publications to his credit.

Mr. Adepoju is not a member of any professional society.

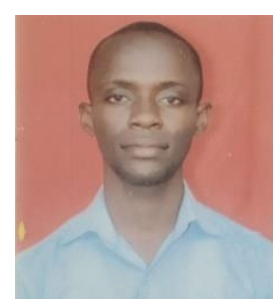

P. Kururimam was born in Makurdi, Benue State, Nigeria on the $2^{\text {nd }}$ of November 1997. He attended the Federal University of Agriculture Makurdi, Benue State Nigeria where he obtained his Bachelor of Science Degree in Industrial Physics in the year 2021.

$\mathrm{He}$ is an alumnus of the Federal University of Agriculture Makurdi, Benue State Nigeria. 